\title{
Improving Self-Efficacy and Physical Self-Reliance of Patients with Pulmonary Tuberculosis through Mindfulness
}

\author{
Erika Dewi Noorratri ${ }^{1}$, Ani Margawati ${ }^{2}$, Meidiana Dwidiyanti $^{3}$ \\ ${ }^{1}$ Department of Nursing Diponegoro University \\ ${ }^{2}$ Department of Nutrition, Diponegoro University \\ ${ }^{3}$ Department of Nursing, DiponegoroUniversity \\ Corresponding author: Meidiana Dwidiyanti (meidiana@fk.undip.ac.id)
}

\begin{abstract}
Background: Patients with pulmonary tuberculosis (TB) have a low level of medication adherence due to long care terms, side effects of medication and self-awareness. This awareness can be promoted by practicing mindfulness.

Purpose: The study aimed to analyze the improvement of self-efficacy and self-reliance of patients with pulmonary TB through mindfulness intervention.

Methods: This study employed a quasi-experiment with pre-post-test group design. The sampling technique was purposive sampling with 19 patients in the intervention group and 19 patients in the control group. The intervention given was mindfulness. The data were analyzed using the Wilcoxon and delta tests.

Results: The study showed an increase of self-efficacy and physical self-reliance in patients in the intervention group with a $p$-value of $<0.05$. In the intervention group, there were differences in the activities of taking medication, eating, sleeping, preventing infection, practicing and coping with physical symptoms before and after the intervention. Furthermore, the patients in the intervention group also showed differences in their increased confidence to recover. Mindfulness intervention provided good effects on the patients in the intervention group as it helped them develop more awareness.

Conclusion: Mindfulness intervention improved the self-efficacy and physical selfreliance of the patients with pulmonary TB. This study recommends that nurses should apply mindfulness to promote the awareness of the patients.
\end{abstract}

Keywords: Mindfulness; self-efficacy; self-reliance; patients with pulmonary TB 


\section{BACKGROUND}

Pulmonary TB is a contagious disease which can be the risk factor of death. Every year, approximately 9 million new cases of TB emerge and cause the death of nearly 2 million people. This disease exists in all countries worldwide, and of all the cases, the majority occur in Africa (30\%) and Asia (55\%). Both China and India contribute to an account for $35 \%$ of all TB cases in the world (WHO, 2013).

Drug-resistant TB is a state in which the M. Tuberculosis bacteria cannot be killed with one or more anti-TB drugs. WHO in 2013 estimated that in Indonesia, every year there are 6,800 new cases of multidrug-resistant (MDR) TB. It is estimated $2 \%$ of these new cases, and $12 \%$ of re-treated cases are MDR. Furthermore, it is also predicted that more than $55 \%$ of patients with MDR-TB have not been diagnosed or given medication properly (MHRI, 2016). In 2009 to 2011, the number of reported rifampicin-resistant (RR) and multidrug-resistant (MDR) cases in Indonesia was 148, 550 and 1225 respectively. This number increased in 2012 to 2014 as many as 2441, 3831 and 9244, in which the highest statistic was found in 2014. In total, the number of TB cases in Indonesia since 2009 to 2014 was 174,693 (MHRI, 2016).

There were several factors which cause the increasing number of the RR and MDR TB cases. Some of which are the limited and unevenly distributed facilities for TB treatment, the unavailability and unevenly distributed referral hospitals and other supporting hospitals which take care of the MDR-TB cases in 34 provinces in Indonesia. In addition, not all hospitals have a good program of Directly Observed Treatment, Short-course (DOTS) (MHRI, 2016).

Based on the patients' point of view, the RR and MDR-TB cases occur due to a low level of adherence to medication, which can develop from the side effects of drugs and low awareness to recover (MHRI, 2016). This low awareness emerges for patients with TB should undergo regular treatment in a long term (about 6 months). As a result, the patients might get tired and bored, which will therefore decrease their awareness.

In addition to self-awareness, self-reliance is also important for patients with TB for their recovery. Norris, et al. (2003) stated that self-reliance is vital in managing diseases such as TB. Self-reliance means helping oneself physically and mentally and reducing depression and pain to improve the quality of life. Orem (2001) mentioned some levels of self-reliance, including being unable to perform, being able to perform in full support of families, being able to perform in partial support of families, and being able to perform independently. The awareness of the importance of self-reliance makes the patients learn the knowledge and skills to practice to be resilient.

Self-reliance has an association with self-efficacy. By self-efficacy is meant the belief of an individual which is required to achieve a specific outcome regarding his ability to complete and organize tasks (Adicondro \& Purnamasari, 2011). Self-efficacy is the belief which can guide patients into an increased self-reliance (Dwidiyanti, 2014). The level of self-reliance includes: being unable to perform, having a desire to learn, being in the need of frequent reminders, being rarely reminded and being self-reliant. Meanwhile, the forms of self-reliance may include taking medication, eating, sleeping, preventing infection 
(disease transmission), practicing and coping with physical symptoms (Dwidiyanti, 2014). Self-reliance can be promoted by practicing mindfulness.

Mindfulness is a process of learning to focus the attention on the present events with no criticisms against them. Such attention is an alternative to lower or to address worries regarding the past and future events (Salmon et al., 2004). The goal of mindfulness is to help someone develop a full awareness of the experiences occurring from time to time. Creswell et al. (2009) carried out a study on the effects of mindfulness on HIV disease. The results showed that mindfulness meditation and stress reduction programs prevented the decline of CD4+ lymphocytes in adult patients with HIV-1 with the mean of CD4+T lymphocyte at baseline as much as 618 cells $/ \mathrm{mm}^{3}$ and $628 \mathrm{cells} / \mathrm{mm}^{3}$ after the intervention with a p-value of 0.09. Cardaciotto et al. (2008) stated that mindfulness promotes the acceptance of awareness to an individual. Another study claimed that the benefits of mindfulness included reducing stress, promoting acceptance of the disease, changing behaviors to better conditions, promoting self-control and tolerance, improving flexibility, emotional intelligence, and mental health, as well as improving relationships with others and oneself with kindness, acceptance, and affection (Davis \& Hayes, 2011).

Self-reliance in patients with pulmonary TB has not been well developed and implemented within the individuals. Since there are few studies examining mindfulness, especially for patients with pulmonary $\mathrm{TB}$, it is, therefore, very necessary to conduct a study which focus on the effects of mindfulness on self-efficacy and self-reliance among patients with pulmonary TB.

\section{OBJECTIVE}

The study aimed to analyze the improvement of self-efficacy and self-reliance of patients with pulmonary TB through mindfulness intervention.

\section{METHODS}

This study employed a quasi-experiment with pre-post-test group design and was conducted from June to July 2016. This study had been approved by the Ethics Committee of the Faculty of Medicine, Diponegoro University, Indonesia. The population was all pulmonary TB patients at the Community Center for Lung Health (CCLH) and Public Health Centers (PHCs) in Magelang. The inclusion criteria were TB patients undergoing treatment at the CCLH, had problems of self-reliance in their treatment, obtained partial assistance from the family, did not leave their region / home during the study, were of age 40-75 years and had a standard monthly income. The sampling technique was purposive sampling with 19 patients in the intervention group and 19 patients in the control group. The intervention given was mindfulness. The research instrument was a questionnaire of the independent health card. The patients were requested to fill out the questionnaire to measure their level of self-efficacy and self-reliance. The data were analyzed using the Wilcoxon and delta tests. 


\section{RESULTS}

Table 1. Homogeneity of respondents in the intervention group $(n=19)$ and control group $(n=19)$

\begin{tabular}{|c|c|c|c|c|c|}
\hline \multirow[t]{2}{*}{ Variables } & \multicolumn{2}{|c|}{$\begin{array}{c}\text { Intervention Group } \\
(n=19)\end{array}$} & \multicolumn{2}{|c|}{$\begin{array}{c}\text { Control Group } \\
(\mathbf{n}=19)\end{array}$} & \multirow[t]{2}{*}{$\mathbf{p}$} \\
\hline & $\mathrm{f}$ & $\%$ & $\mathrm{f}$ & $\%$ & \\
\hline \multicolumn{6}{|l|}{ Sex } \\
\hline Male & 10 & 52.63 & 12 & 63.15 & \multirow[t]{2}{*}{0.508} \\
\hline Female & 9 & 47.36 & 7 & 36.84 & \\
\hline \multicolumn{6}{|l|}{ Age (years) } \\
\hline $40-49$ & 5 & 26.31 & 5 & 26.31 & \multirow[t]{4}{*}{0.546} \\
\hline $50-59$ & 9 & 47.36 & 6 & 31.57 & \\
\hline $60-69$ & 5 & 26.31 & 6 & 31.57 & \\
\hline$>70$ & - & & 2 & 10.52 & \\
\hline \multicolumn{6}{|l|}{ Distance from home } \\
\hline $1-3 \mathrm{~km}$ & 12 & 63.15 & 17 & 89.47 & \multirow[t]{3}{*}{0.574} \\
\hline $4-6 \mathrm{~km}$ & 7 & 36.84 & 1 & 5.26 & \\
\hline 7-9 km & - & & 1 & 5.26 & \\
\hline \multicolumn{6}{|l|}{ Income } \\
\hline Low income & 12 & 63.15 & 8 & 42.10 & \multirow[t]{2}{*}{0.490} \\
\hline High income & 7 & 36.85 & 11 & 57.9 & \\
\hline \multicolumn{6}{|l|}{ Marital status } \\
\hline Married & 13 & 68.42 & 18 & 94.73 & \multirow[t]{2}{*}{0.121} \\
\hline Unmarried & 6 & 31.58 & 1 & 5.27 & \\
\hline \multicolumn{6}{|l|}{ Occupation } \\
\hline Unemployed & 2 & 10.523 & 3 & 15.78 & \multirow[t]{2}{*}{0.020} \\
\hline Employed & 17 & 89.48 & 16 & 84.21 & \\
\hline \multicolumn{6}{|l|}{ Education } \\
\hline Low level & 13 & 68.42 & 16 & 84.21 & \multirow[t]{2}{*}{0.689} \\
\hline High level & 6 & 31.58 & 3 & 15.79 & \\
\hline \multicolumn{6}{|l|}{ Other diseases } \\
\hline $\begin{array}{l}\text { Suffered from } \\
\text { another disease }\end{array}$ & 2 & 10.52 & 5 & 26.31 & \multirow[t]{2}{*}{0.202} \\
\hline $\begin{array}{l}\text { Never suffered from } \\
\text { another disease }\end{array}$ & 17 & 89.48 & 12 & 73.69 & \\
\hline
\end{tabular}

Mindfulness intervention was administered by firstly determining the samples of the new patients with pulmonary TB who visited and had their treatment at the CCLH for the first time. An informed consent was assigned to the patients prior to the study. An agreement regarding the schedule for mindfulness was also made between the researchers and the patients. The program of mindfulness was arranged to be implemented once a week. In the control group, no intervention of mindfulness was given. The patients in this group were only given health education about TB disease. These patients were taken from the data of the PHC in Magelang. The researchers visited the patients for the study purposes. 
Table 2. Scores of pre and post-test of the self-efficacy of the participants in the intervention and control groups

\begin{tabular}{|c|c|c|c|c|c|c|}
\hline \multirow[t]{2}{*}{$\begin{array}{l}\text { Self-Efficacy } \\
\text { Variable }\end{array}$} & \multicolumn{3}{|c|}{$\begin{array}{c}\text { Intervention Group } \\
(\text { Mean } \pm \text { SD })\end{array}$} & \multicolumn{3}{|c|}{$\begin{array}{l}\text { Control Group } \\
\text { (Mean } \pm \text { SD) }\end{array}$} \\
\hline & pre & post & $\begin{array}{c}\text { p- } \\
\text { value }\end{array}$ & pre & post & $\begin{array}{c}\text { p- } \\
\text { value }\end{array}$ \\
\hline $\begin{array}{l}\text { Confidence to } \\
\text { heal }\end{array}$ & $(3.74 \pm 1.147)$ & $(9.95 \pm 0.229)$ & 0.000 & $(6.84 \pm 4.776)$ & $(6.84 \pm 4.776)$ & 1.000 \\
\hline $\begin{array}{l}\text { Confidence to } \\
\text { cope with pain }\end{array}$ & $(3.37 \pm 1.165)$ & $(9.05 \pm 1.026)$ & 0.000 & $(3.95 \pm 3.566)$ & $(3.95 \pm 3.566)$ & 1.000 \\
\hline $\begin{array}{l}\text { Confidence to } \\
\text { be able to do } \\
\text { self-care }\end{array}$ & $(4.05 \pm 1.224)$ & $(9.16 \pm 1.259)$ & 0.000 & $(2.89 \pm 3.843)$ & $(2.89 \pm 3.843)$ & 1.000 \\
\hline
\end{tabular}

The result of the Wilccoxon-test showed a p-value $<0.05$ in the intervention group, indicating that there were a significant difference in self-efficacy among the patients. The participants in the control group did not show any increase in their self-efficacy as evidenced with a value of $p=1.000$ ( $p>0.05$ ). Mindfulness intervention was able to reduce the patients' emotions and stress, encourage the patients to take their medication regularly, enable the patients to sleep well and be aware of the importance of eating. Furthermore, it also made the patients feel calm and relaxed, take the medication independently, aware of the surrounding environment, not ashamed of wearing a mask to prevent infection, develop sincerity, accept their illness and make the efforts to recover by taking medicine regularly, as well as increase their appetite.

Table 3. Scores of pre and post-test on the self-reliance of the participants in the intervention and control groups

\begin{tabular}{lcccccc}
\hline $\begin{array}{c}\text { Variable of } \\
\text { Physical Self- } \\
\text { reliance }\end{array}$ & \multicolumn{3}{c}{$\begin{array}{c}\text { Intervention Group } \\
\text { (Mean } \pm \text { SD) }\end{array}$} & \multicolumn{5}{c}{ Control Group (Mean \pm SD) } \\
\cline { 2 - 7 } & pre & post & $\begin{array}{c}\text { p- } \\
\text { value }\end{array}$ & pre & post & $\begin{array}{c}\text { p- } \\
\text { value }\end{array}$ \\
\hline $\begin{array}{l}\text { Taking } \\
\text { medication }\end{array}$ & $(3.84 \pm 1.068)$ & $(1.53 \pm 0.841)$ & 0.000 & $(3.42 \pm 0.507)$ & $(3.42 \pm 0.507)$ & 1.000 \\
Eating & $(4.37 \pm 0.761)$ & $(2.53 \pm 0.772)$ & 0.000 & $(2.63 \pm 0.684)$ & $(2.63 \pm 0.684)$ & 1.000 \\
Sleeping & $(4.79 \pm 0.535)$ & $(3.05 \pm 0.705)$ & 0.000 & $(2.63 \pm 1.802)$ & $(2.58 \pm 1.742)$ & 0.317 \\
$\begin{array}{l}\text { Preventing } \\
\text { infection }\end{array}$ & $(4.95 \pm 0.229)$ & $(3.47 \pm 0.513)$ & 0.000 & $(2.74 \pm 0.806)$ & $(1.84 \pm 0.602)$ & 1.000 \\
$\begin{array}{l}\text { Practicing } \\
\begin{array}{l}\text { Coping with } \\
\text { physical }\end{array}\end{array}$ & $(5.00 \pm 0.000)$ & $(3.89 \pm 0.315)$ & 0.000 & $(3.58 \pm 1.705)$ & $(1.84 \pm 0.602)$ & 0.000 \\
symptoms & $(5.00 \pm 0.000)$ & $(4.16 \pm 0.501)$ & 0.000 & $(3.53 \pm 1.502)$ & $(1.95 \pm 0.524)$ & 0.000 \\
\hline
\end{tabular}

Table 4. Delta value of physical self-reliance of participants in the intervention and control groups

\begin{tabular}{lcc}
\hline \multicolumn{1}{c}{ Variable of Self-Reliance } & $\begin{array}{c}\text { Delta Score in the Intervention Group } \\
\text { and Control Group (Mean } \pm \text { SD) }\end{array}$ & p-value \\
\hline Taking medication & $(1.63 \pm 0.171)$ & 0.001 \\
Eating & $(0.9474 \pm 0.025)$ & 0.007 \\
\hline
\end{tabular}




\begin{tabular}{lcc}
\hline \multicolumn{1}{c}{ Variable of Self-Reliance } & $\begin{array}{c}\text { Delta Score in the Intervention Group } \\
\text { and Control Group (Mean } \pm \text { SD) }\end{array}$ & p-value \\
\hline Sleeping & $(0.6842 \pm 0.334)$ & 0.194 \\
Preventing infection & $(0.2631 \pm 0.114)$ & 0.132 \\
Practicing & $(1.1578 \pm 0.358)$ & 0.058 \\
Coping with physical symptoms & $(1.2106 \pm 0.052)$ & 0.001 \\
\hline
\end{tabular}

In the control group, no changes were found regarding the physical self-reliance in terms of taking medication, eating, sleeping and prevention of infection with a value of $p>0.05$. Meanwhile, self-reliance in terms of practicing and coping with physical symptoms experienced changes with a p-value $<0.05$.

\section{DISCUSSION}

\section{Demographic Characteristics of the Participants}

The data indicated that the majority of the participants were men with a total number of $22(57.89 \%)$. This is similar to a study by Erawatyningsih et al. (2009) which found that male gender was more susceptible to TB due to their work, lack of rest, and unhealthy lifestyle such as smoking and drinking alcohol. At the CCLH in Magelang, the majority of patients had a low level of education (no formal school and elementary school only) as many as $29(76.31 \%)$. The low level of education became a factor affecting the adherence to medication of the patients with pulmonary TB (Erawatyningsih et al., 2009). Therefore, patients with a low education need to be given counseling and health education to increase their knowledge. The failure of the medication experienced by patients is associated with the lack of knowledge (Rusadi, 2012).

The survey also revealed that patients with pulmonary TB were mostly employed with a total number of 17 (89.48\%). Erawatyningsih et al. (2009) indicated that people who are employed will have a high load which includes both physical and mental. Some studies suggested that people who work tend to have less rest than those who do not work. Rukmini and Chatarina (2010) stated that many patients with pulmonary TB are not employed.

\section{Self-Efficacy of Patients with Pulmonary TB after Mindfulness Intervention in the Intervention Group}

Individuals who have a high level of self-efficacy will have the confidence to complete various tasks and organize various difficulties (Dwidiyanti, 2014). In this study, selfefficacy in the intervention group showed a significant increase with a p-value of 0.000 $(\mathrm{p}<0.05)$. The patients demonstrated self-efficacy and practices with awareness, and were able to maintain such practices every day. This is similar to a study by Chiesa and Serretti (2011) which found that mindfulness gave effects on someone's self-efficacy. Mindfulness-based interventions reduced the pain, the symptoms of depression associated with chronic pain and anxiety. Furthermore, it also improved self-efficacy and affected the self-management in patients with rheumatoid arthritis. The patients were able to improve their self-efficacy and to practice and maintain it daily. The findings in this study confirm the study by Chiesa and Serretti (2011) which found that mindfulness improved the self-efficacy of TB patients. 
A study by Beatriks and Indra (2015) concluded that self-efficacy gives effects on the psychological state of an individual. Self-efficacy gives the individual ability to control stress and anxiety. The belief in one's self-efficacy will lead the individual to be aware of what he/she wants to do. This relates to the evidence that mindfulness can make someone aware of himself. Therefore, mindfulness affects the self-efficacy of patients with pulmonary TB.

\section{Self-Efficacy of the Patients in the Control Group}

The patients in the control group did not show any significant improvement in their selfefficacy with a $\mathrm{p}$-value of 1.000 ( $\mathrm{p}>0.05$ ). No intervention of mindfulness was given to these patients, and therefore no increase in self-efficacy was identified. The findings of recent studies showed that self-awareness is required by the patients to perform selfefficacy, and to practice and maintain it every day. The awareness of the patients is developed from mindfulness. The patients in the control group in this study did not show any increase in their efficacy as they were not yet aware of the importance of self-efficacy. Self-efficacy influences the psychological states of the individuals (Beatriks \& Indra, 2015)

\section{Physical Self-Reliance of Patients with Pulmonary TB after Mindfulness Intervention in the Intervention Group}

The hypothesis of the present study which stated that there was an increase of self-reliance of the pulmonary TB patients through mindfulness intervention was accepted.

The findings showed a significant increase in the physical self-reliance of the patients in the intervention group after they were given the mindfulness intervention with a $p$-value of $0.000(\mathrm{p}<0.05)$. This indicated a significant difference before and after the intervention. Previous studies stated that mindfulness helped the patients to have a better life. The intervention of mindfulness in the present study was considered successful as it assisted the patients to have a better cooperation with other people and groups. It also increased the level of creativity, motivation to work and interpersonal communication. Therefore, these findings confirm the study by Herawanti (2016).

The intervention of mindfulness also develops the emotional intelligence and social intelligence of an individual so as to face reality with a good response and a controlled ego. This individual will have a focused attention on every situation in details and awareness in reading the situation around. In practice, mindfulness can develop a feeling of relaxed (not depressed) as evident in the study by Kartasasmita (2013). The findings in the present study showed similarities with the study by Kartasasmita (2013).

In some other studies, it was found that mindfulness also gave positive effects and improved wellness, decreases psychological symptoms and emotional reactivity and promoted positive behaviors (Keng et al., 2011). Mindfulness helped someone to live more healthily and view things in more positive ways. It also helped people to avoid depression, develop relationships with others, improve self-esteem, increase body immunity, and prevent the possibility from using illegal drugs (Erawatyningsih et al., 2009). Mindfulness has been associated with the physical and mental wellness and enables someone to control oneself, emotions, and lower the level of anxiety and symptoms of depression (Olson \& Emery, 2015). Other studies also indicated that 
mindfulness provides benefits to reduce stress and increase the feeling of acceptance as well as lead to better behaviors. In addition, it also develops and promotes self-control, tolerance, flexibility, emotional intelligence, mental health, and relationships with oneself and others with kindness, acceptance and affection. The results of the present study are similar to the study by Davis and Hayes (2011).

Mindfulness raises the awareness of individuals to do practices for their physical selfreliance daily. These practices are performed by the patients every day and should be regularly maintained. Therefore, the patients will learn to be physically reliant. The physical self-reliance of the pulmonary TB patients, which includes taking medication, sleeping, eating, prevention of disease transmission, practicing, and coping with physical symptoms can be promoted by the mindfulness intervention. Mindfulness develops the awareness of the individuals. The results of self-reliance in terms of taking medication in patients in the intervention group significantly increased with a p-value of $0.000(\mathrm{p}<0.05)$. Furthermore, the patients with sleeping disturbance could finally have their sound sleep as indicated with a p-value of $0.000(\mathrm{p}<0.05)$. In this context, mindfulness makes the mind calm and focused on current attention will enable the individuals to feel more relaxed and aware of their physical needs to stay strong by having regular and sound sleep (Dwidiyanti, 2014). The physical self-reliance in terms of eating also significantly increased in patients in the intervention group with a p-value of $0.000(\mathrm{p}<0.05)$. Mindfulness helped the patients increase their appetite since they were aware of the importance of eating to maintain a healthy body. Related to the prevention of disease transmission, the patients in the intervention group showed an increase in their prevention efforts with $\mathrm{p}$-value $=0.000(\mathrm{p}<0.05)$. Mindfulness enabled them to focus their attention to protecting other people nearby from TB infection (Dwidiyanti, 2014). Regarding physical self-reliance in terms of practicing, it was found that there was a significant increase in patients in the intervention group. In addition, there was also a significant increase of coping with physical symptoms with $\mathrm{p}=0.000(\mathrm{p}<0.05)$. Mindfulness provided a great benefit to patients in overcoming the symptoms of TB. All forms of physical self-reliance of the patients could be promoted through practices, and the patients were able to maintain these practices.

\section{Physical Self-reliance in Patients in the Control Group}

Based on the results of data analysis, it was concluded that there were changes of physical self-reliance of the patients in the control group in terms of practices and coping with physical symptoms with the value of $p=0.000$ ( $p<0.05$ ). This condition could be caused by several other factors, though no mindfulness intervention was given. From the demographic characteristics of the patients in the control group, it was revealed that the employment status was significantly different from the patients in the intervention group that might influence the result of the study.

\section{CONCLUSION}

This study provided evidence on the effect of mindfulness on enhancing self-efficacy and physical self-reliance of the patients with pulmonary TB. Nurses could use this program to encourage the patients' self-awareness to control their condition. The future studies could examine the effect of mindfulness on the caregivers or family of patients with pulmonary TB. 


\section{ACKNOWLEDGEMENT}

The authors would like to thank the CCLH of Magelang, the Department of Health of Magelang Regency, and the Public Health Centers (PHCs) in Magelang for giving the authors opportunity and permission to conduct the study in their areas.

\section{REFERENCES}

Adicondro, N., \&Purnamasari, A. (2011). Efikasi diri, dukungan sosial keluarga dan selfregulated learning pada siswa kelas VIII [Self-efficacy, family social support and self-regulated learning in students of eight grade]. Humanitas, 8(1), 17-27.

Beatriks N., B. \& Indra, Y. K. (2015). Efikasi diri dan pengukurannya pada orang usia lanjut [self-efficacy and its assessment in elderly]. Seminar Nasional Educational Wellbeing. UMK.

Cardaciotto, L., Herbert, J. D., Forman, E. M., Moitra, E., \& Farrow, V. (2008). The assessment of present-moment awareness and acceptance: the Philadelphia mindfulness scale. Assessment, 15(2), 204-223.

Chiesa, A. \& Serretti, A. (2011). Mindfulness-based interventions for chronic pain: A systematic review of the evidence. The Journal of Alternative and Complementary Medicine, 17(1), 83-93. DOI : 10.1089/acm.2009.0546.

Creswell J. D., Myers H. F., Cole S. W., \& Irwin, M. R. (2009). Mindfulness meditation training effects on CD4+ T lymphocytes in HIV-1 infected adults: A small randomized controlled trial single-blind randomized controlled trial. Brain, Behaviour, and Immunity. 23 (2), 184-188.

Davis, D. M., \& Hayes, J. A. (2011). What are the benefits of mindfulness? A practice review of psychotherapy-related research. Psychotherapy, 48(2), 198-208. DOI: 101037/a0022062.

Dwidiyanti, M. (2014). Intervensi keperawatan holistik program Sowan melalui target sehat mandiri pada pasien TB paru [Intervention of holistic program of SOWAN through independent health card in pulmonary TB patients]. Konferensi Nasional PPNI Jawa Tengah [Proceeding of National Conference of PPNI of Central Java]. http://jurnal.unimus.ac.id/index.php/psn12012010/article/view/1119/1173

Erawatyningsih, E., Purwanta, \& Subekti, H. (2009). Faktor-Faktor yang mempengaruhi ketidakpatuhan berobat pada pasien tuberculosis paru [Factors influencing nonadherence to medication of patients with pulmonary TB]. Berita Kedokteran Masyarakat, 25 (3), 117-124.

Herawanti, H.. (2016). Pengaruh pelatihan mindfulness service terhadap sikap pelayanan prima [Effects of mindfulness service on the behaviors of service excellence]. Unpublished Thesis of the Muhammadiyah University of Surakarta.

Kartasasmita, S. (2013). Hubungan kepribadian big five (Neo-Pi) dengan mindfulness pada mahasiswa [Relationship between big five personality and mindfulness in university students]. A Conference Paper, Universitas Tarumanegara.

Keng, S. L., Smoski, M. J., \& Robin, C. J. (2011). Effects of mindfulness on psychological health: A review of empirical Studies. Clinical Psychology Review. 31(6), 1041-1056.

Ministry of Health Republic of Indonesia (MHRI). (2016). Infodatin_TB. Retrieved April 14, 2016, from

http://www.depkes.go.id/resources/download/pusdatin/infodatin/infodatin_tb.pdf

Norris, S. L., Nichols, P. J., Caspersen, C. J., Glasgow, R. E., Engelgau, M. M., Jack Jr, L.,... McCulloch, D. (2003). Increasing diabetes self-management education in community settings. American Journal of Preventive Medicine. 22(4), 39-66. 
Olson, K. L. L., \& Emery, C. F. (2015). Mindfulness and weight loss: A systematic review. Psychosomatic Medicine, 77, 59-67. DOI: 0033-3174/15/7701-0059.

Orem, D. E. (2001). Nursing Concepts of practice. Michigan: Mosby.

Rukmini, \& Chatarina, U. W. (2014). Kejadian TB paru dewasa di Indonesia (analisis data riset kesehatan dasar Tahun 2010) [Incidence of pulmonary TB in adults in Indonesia. (An analysis of basic health research year 2010)]. Buletin Penelitian Sistem Kesehatan, 14(4), 320-331.

Rusadi, M. (2012). Hubungan pengetahuan dengan kegagalan pengobatan tuberculosis di Puskesmas Antang Kecamatan Manggala Kota Makassar [Relationship between knowledge and treatment failure of tuberculosis at primary health center]. Unpublished thesis. Universitas Hasanudin Makasar.

Salmon, P., Sephton, I., Weissbecker, I., Hoover, K., Ulmer, K., \& Jamie, L. (2004). Mindfulness meditation in clinical practice. Cognitive and Behavioral Practice, 11, 434-446.

WHO. (2013). WHO Report on Global Tuberculosis Control. Retrieved April 16, 2016, from http://www.who.int/tb/data. 